\title{
PENDAPATAN BAGI HASIL DAN PERLAKUAN AKUNTANSI \\ PADA BANK SYARIAH \\ (STUDI PADA BANK MANDIRI SYARIAH CABANG KOTA BAUBAU)
}

\author{
Ernawati Malik \\ Program Studi Akuntansi, Fakultas Ekonomi, \\ Universitas Muhammadiyah Buton, Baubau, Indonesia \\ Email : ernamalik8975@gmail.com
}

\begin{abstract}
ABSTRAK
Tujuan penelitian ini adalah untuk mengetahui pendapatan bagi hasil dan perlakuan akuntansi pada bank syariah dengan studi pada Bank Mandiri Syariah Cabang Kota Baubau. Penelitian ini menggunakan analisis deskriptif kualitatif untuk menganalisis data yang diperoleh.. Berdasarkan hasil analisi data dapat ditarik kesimpulan bahwa ada dua akad yang digunakan oleh Bank Mandiri Syariah Cabang Kota Baubau dalam bagi hasil yaitu akad mudharabah dan akad musyarakah sesuai PSAK 105 (paragraph 4) dan PSAK 106 dan pengukuran keunungan/kerugiannya. Perhitungan bagi hasil untuk nasabah telah ditentukan melalui rumus yang telah disediakan.
\end{abstract}

Kata Kunci : Pendapatan, Bagi Hasil, Perlakuan Akuntansi

\section{ABSTRACT}

The purpose of this study was to determine the revenue sharing and accounting treatment of Islamic banks by studying at Bank Mandiri Syariah, Baubau Ciy Branch. This study uses qualitative descriptive analysis to analyze the data obtained. Based on the result of data analysis, it can be concluded that there are two contracts used by Bank Mandiri Syariah in Baubau City Branch in profit sharing, namely : mudharabah contract and musyarakah contract in accordance with PSAK 105 (paragraph 4) and PSAK 106 and recognition of their profits/losses. Calculation of profir sharing for customers has been determined through the formula provided.

Keywords : Income, Profit Sharing, Accounting Treatment 


\section{PENDAHULUAN}

Sistem bunga telah mendominasi perekonomian dunia selama ratusan tahun.Hampir semua perjanjian di bidang ekonomi dikaitkan dengan bunga. Sistem ekonomi kapitalis yang berbasis bunga (interest base) menempatkan uang sebagai komoditi yang dapat diperdagangkan. Hal ini memberikan implikasi yang serius terhadap kerusakan hubungan ekonomi yang adil dan produktif.

Perbankan Syariah merupakan segala sesuatu yang menyangkut tentang bank umum syariah dan unit usaha syariah, baik itu menyangkut kelembagaan, kegiatan usaha, cara, dan proses dalam melaksanakan kegiatan usahanya. Perbedaan antara bank konvensional dan bank syariah yang paling mendasar adalah pembagian keuntungan, dimana bank konvensional menerapkan sistem bunga sebagai langkah mengendalikan tingkat inflasi, sedangkan bank syariah menerapkan sistem bagi hasil [1].

Banyak yang melatarbelakangi perkembangan bank syariah, mulai dari perbedaan dengan bank konvensional yang mendasar hingga yang paling spesifik.Untuk itu penulis merasa tertarik untuk melakukan penelitian pada pendapatanbagi hasil dan perlakuan akuntansi pada bank syariah dengan studi pada Bank Mandiri Syariah Cabang Kota Baubau. Tujuan dari penelitian ini adalah untuk mengetahui bagi hasil dan perlakuan akuntansi pada bank Mandiri Syariah Cabang Kota Baubau.

\section{METODE PENELITIAN}

\section{Populasi dan Sampel}

Populasi adalah wilayah generalisasi yang terdiri atas objek/subjek yang memiliki kualitas dan karakteristik tertentu yang ditetapkan oleh peneliti untuk dipelajari dan kemudian ditarik kesimpulan [2]. Populasi pada penelitian ini adalah pendapatan bagi hasil dan perlakuan akuntansi pada bank syariah. Sampel pada peneltian ini adalah pendapatan bagi hasil pada bank syariah periode 2016-2017. 


\section{Jenis dan Sumber Data}

Data yang digunakan dalam penelitian ini adalah data kualitatif dan kuantitatif. Data Kualitatif yaitu data yang disajikan dalam bentuk kata verbal bukan dalam bentuk angka [3]. .Data kualitatif dalam penelitian ini yaitu gambaran umum obyek penelitian. Data kuantitatif adalah jenis data yang dapat diukur atau dihitung secara langsung, yang berupa informasi atau penjelasan yang dinyatakan dengan bilangan atau berbentuk angka. [4].

Sumber data dalam penelitian ini adalah data primer dan data sekunder. Data primer adalah data yang mengacu pada informasi yang diperoleh dari tangan pertama oleh peneliti yang berkaitan dengan variabel minat untuk tujuan spesifik studi. Dalam penelitian kualitatif ialah kata-kata dan tindakan yang diperoleh dari lapangan dengan pengamatan atau wawancara [5]. Peneliti menggunakan data ini untuk mendapatkan informasi langsung tentang pendapat bagi hasil dan perlakuan akuntansi pada Bank Mandiri Syariahyang telah dikumpulkan melalui wawancara langsung dengan karyawan Bank Mandiri Syariah.

Data sekunder adalah data yang mengacu pada informasi yang dikumpulkan dari sumber yang telah ada [6]. Peneliti menggunakan data sekunder ini untuk memperkuat penemuan dan melengkapi informasi.

\section{Teknik Pengumpulan Data}

Teknik pengumpulan data yang digunakan pada penelitian ini adalah observasi, wawancara, dan dokumentasi. Observasi merupakan suatu proses yang kompleks, suatu proses yang tersusun dari berbagai proses biologis dan psikologis [7]. Dua di antara yang terpenting adalah proses-proses pengamatan dan ingatan.Dalam kegiatan sehari-hari, kita selalu menggunakan mata untuk mengamati sesuatu. Observasi ini digunakan untuk penelitian yang telah direncanakan secara sistematik.

Wawancara merupakan pertemuan dua orang untuk bertukar informasi dan ide melalui tanya jawab, sehingga dapat dikontruksikan makna dalam suatu topik tertentu.dokumen merupakan catatan peristiwa yang sudah 
berlalu. Dokumen bisa berbentuk tulisan, gambar, atau karya-karya monumental dari seseorang. Dokumentasi adalah setiap bahan tertulis baik berupa karangan, memo, pengumuman, instruksi, majalah, buletin, pernyataan, aturan suatu lembaga masyarakat, dan berita yang disiarkan kepada media massa [2]. Dari uraian di atas maka metode dokumentasi adalah pengumpulan data dengan meneliti catatan-catatan penting yang sangat erat hubungannya dengan obyek penelitian.

\section{Teknik Analisis Data}

Setelah data dari lapangan terkumpul dengan menggunakan metode pengumpulan data di attas, data akan diolah dan dianalisis menggunakan analisis deskriptif kualitatif.

Analisis deskriptif kualitatif merupakan suatu teknik yang menggambarkan dan mempresentasikan arti dari data-data yang terkumpul dengan memberikan perhatian dan merekam sebanyak mungkin aspek situasi yang diteliti pada saat itu, sehingga memperoleh gambaran secara umum dan menyeluruh tentang keadaan sebenarnya.

\section{HASIL DAN PEMBAHASAN}

\section{Hasil Penelitian}

\section{Sistem Bagi Hasil Dalam Bank Mandiri Syariah Cabang Kota Baubau}

Bank Mandiri Syaria Cabang Kota Baubau memiliki sistem bagi hasil yang digunakan dalam menjalankan proses bagi hasil sesuai persyaratan dan peraturan berlaku. Adapun proses sistem bagi hasil dalam Bank Mandiri Syariah Cabang Kota Baubau adalah sebagai berikut. Terdapat dua pendapatan bagi hasil yaitu pendapatan pengelolaan dana dan pendapatan penyaluran.

Pendapatan pengelolaan dana bank Mandiri Syariah adalah pendapatan bank pada bagi hasil atas pengelolaan dana dari nasabah berupa tabungan/deposito. Kemudian dari pendapatan tersebut pihak bank membagi (-/-) hasil pendapatannya kepada hak pemilik dana atas bagi hasil investasi 
tidak terikat (mudharabah mutlaqah). Setelah itu pihak bank mendapat pemasukan $(+/+)$ atas pendapatan pengelolaan dana berupa fee based income. Dari hasil pendapatan itu, pihak bank kembali membagikan (-/-) pendapatan berupa beban mudharib (beban tenaga kerja, administrasi dan operasional lainnya) dan menhasilkan laba/rugi dari pendapatan pengelolaan dana tersebut.

Pendapatan penyaluran adalah pendapatan bank pada bagi hasil atas pengelolaan dana berupa surat berharga, jual beli dan sebagainya. Dari pendapatan tersebut pihak bank melakukan pengelolaan surat berharga, jual beli dan sebagainya sehingga menghasilkan pendapatan atas kinerja tersebut. Kemudian pihak bank melakukan pembagian (-/-) atas kinerja tersebut berupa beban pengelolaan mudharabah (beban tenaga kerja, administrasi, oprasional lainnya). Setelah pembagian, pihak mendapatkan hasil berupa laba/rugi mudharabah.

\section{Komponen Menghitung Bagi Hasil untuk Nasabah pada Bank Syariah}

Dalam menghitung bagi hasil yang diterima oleh masing-masing nasabah harus diperoleh/tersedia data antara lain sebagai berikut:

a. Jumlah/saldo simpanan nasabah per jenis simpanan bulan yang bersangkutan.

b. Total saldo rata-rata harian per jenis simpanan nasabah bulan yang bersangkutan.

c. Total pendapatan bagi hasil yang akan distribusikan kepada nasabah per jenis simpanan nasabah bulan yang bersangkutan.

d. Nisbah atau rate bonus bagi hasil dari jenis simpanan nasabah per bulan yang bersangkutan [6]

\section{Tahapan Perhitungan Bagi Hasil Pada Bank Syariah}

Tahapan-tahapan dalam perhitungan bagi hasil pada Bank Mandiri Syariah Cabang Kota Baubau sebagai berikut :

1. Menentukan Bagi Hasil yang akan digunakan

2. Menghitung saldo rata-rata harian sumber dana.

3. Menghitung saldo rata-rata harian penyalur dana. 
4. Menghitung pendapatan yang akan dibagi hasil

5. Menghitung proporsi Bagi Hasil pendapatan untuk setiap jenis sumber data

6. Menghitung pendapatan bagi hasil untuk nasabah dan bank

7. Distribusi bagi hasil pendapatan kepada masing masing nasabah sesuai nisbah yang disepakati

\section{Rumus Perhitungan Bagi Hasil Untuk Nasabah Pada Bank Syariah}

Dalam penentuan bagi hasil, tentunya kebijakan dan kesepakatan awal sangat mempengaruhi pembagian bagi hasil.Kesepakatan antara pemilik modal dan pengelola modal menentukan pembagian bagi hasil atas pengelolaan dana tersebut. Perhitungan bagi hasil untuk nasabah telah ditentukan melalui rumus yang telah disediakan. Adapun rumus perhitungan bagi hasil untuk nasabah sebagai berikut :

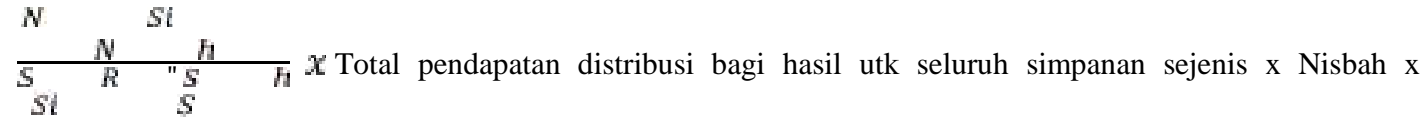

\section{Perhitungan Bagi Hasil Tabungan Mudharabah pada Bank Syariah}

Tabungan mudharabah adalah simpanan pihak ketiga yang penarikannya dapat dilakukan setiap saat atau beberapa kali sesuai dengan perjanjian. Dalam hal ini, bank bertindak sebagai mudharib (pengelola modal) dan deposan sebagai sahib al-mal (pemilik dana). Bank sebagai mudharib akan membagi keuntungan kepada pemilik modal sesuai dengan nisbah (persentase) yang telah disetujui bersama. Pembagian keuntungan dapat dilakukan setiap bulan berdasarkan saldo minimal yang mengendap selama periode tersebut.

\section{Perhitungan Bagi Hasil Deposito Mudharabah Pada Bank Syariah}

Deposito mudharabah adalah merupakan investasi melalui simpanan pihak ketiga (perseorangan atau badan hukum) yang penarikannya hanya dapat dilakukan dalam jangka waktu tertentu (jatuh tempo), dengan mendapatkan 
imbalan bagi hasil. Imbalan ini dibagi dalam bentuk berbagi pendapatan (revenue sharing) atas penggunaan dana tersebut secara syariah dengan proporsi pembagian, misalnya 70:30. Artinya, untuk deposan sebesar 70\% dan untuk bank 30\%.Jangka waktu deposito mudharabah ini berkisar antara 1 tahun, 6 bulan, 3 bulan dan 1 bulan.

\section{Pembahasan}

Pada Bank Mandiri Syariah Cabang Kota Baubau ada dua akad yang sering digunakan dan berkaitan dengan pendapatan bagi hasil, yaitu akad mudharabah dan akad musyarakah. Kebijakan akuntansi pengakuan pendapatan bagi hasil atas akad mudharabah dan akad musyarakah pada Bank Mandiri Syariah Cabang Kota Baubau sebagai berikut:

\section{Akad Bagi Hasil, Pengakuan Keuntungan/Kerugian dan Pengukuran pada Bank Mandiri Syariah Cabang Kota Baubau}

\section{Akad Mudharabah}

“Akad kerjasama usaha antara dua pihak dimana pihak pertama (pemilik dana) menyediakan seluruh dana, sedangkan pihak kedua (pengelola dana) bertindak sebagai pengelola, dan keuntungan dibagi diantara mereka sesuai kesepakatan sedangkan kerugian finansial hanya ditanggung oleh pemilik dana [10]".

\section{a. Pengakuan Keuntungan}

Apabila nasabah memperoleh keuntungan atas usahanya, maka Bank Mandiri Syariah akan mengakui pendapatan dan hak bagi hasil sesuai nisbah yang di tentukan. Namun apabila hasil keuntungan belum terbayarkan, maka pihak bank akan mengakui sebagai piutang.

\section{b. Pengakuan Kerugian}

Apabila terjadi kerugian, maka pihak bank mengakui dan mengurangi pembiayaan mudharabah guna tidak terjadi penyimpangan dalam perolehan pendapatan bagi hasil.Jika kerugian disebabkan oleh kelalaian nasabah, maka kerugian tersebut di bebankan oleh pengeloladana (nasabah). 


\section{c. Pengukuran}

Berdasarkan penelitian pada Bank Mandiri Syariah Cabang Kota Baubau, pembiayaan mudharabah masuk pada piutang dalam neraca, sehingga pembiayaan mudharabah ini diukur dari dana dalam bentuk kas dinilai sebesar jumlah yang diterima. Untuk semua penerimaan pembiayaan mudharabahdiukur sesuai dengan penerimaan keseluruhan dari setiap akun dari penerimaan pembiayaan mudharabah.

\section{Akad Musyarakah}

"Akad kerjasama antara dua pihak atau lebih untuk suatu usaha tertentu, dimana masing-masing pihak memberikan konstribusi dana dengan ketentuan bahwa keuntungan dibagi berdasarkan kesepakatan sedangkan kerugian berdasarkan porsi kontribusi dana[11]"

\section{a. Pengakuan Keuntungan}

Ada dua metode yang digunakan dalam pembagian bagi hasil yaitu :profit and loss sharing dan revenue sharing.

\section{b. Pengakuan Kerugian}

Jika terjadi kerugian, maka bank membuat penyisihan kerugian dan piutang musyarakah yang akan timbul dari transaksi musyarakah.

\section{c. Pengukuran}

Untuk pengukuran pada saat bagi hasil, bank mengakui bagi hasil tersebut pada saat bank terima jumlah dari rekening nasabah sebagai pembayaran bagi hasil kepada bank syariah [8].

\section{Perlakuan Akuntansi Bagi Hasil Bank Syariah}

Dikeluarkanya Pernyataan Standar Akuntansi Keuangan (PSAK) No. 59 tentang Akuntansi Perbankan Syariah oleh Ikatan Akukuntansi Indonesia (IAI) merupakan angin segar bagi praktik akuntansi dibank syariah. Sebab pernyataan ini bertujuan untuk mengatur perlakuan akuntansi (pengakuan, pengukuran, penyajian, dan pengungkapan) transksi khusus yang berkaitan dengan aktivitas bank syariah. Pernyatan ini 
diterapkan untuk bankumum syariah, bank perkreditan rakyat syariah, dan kantor cabang syariah bank konvesional yang beroperasi di Indonesia. Hal-hal umum yang tidak diatur dalam pernyataan ini mengacu pada pernyataan standar akuntansi yang berlaku umum sepanjang tidak bertentangan dengan prinsip syariah.Pernyatan ini bukan merupakan pengaturan penyajian laporan keuangan sesuai permintaan khusus (statuori) pemerintah, lembaga pemerintah independent, dan bank sentral (Bank Indonesia).Usaha bank banyak dipengaruhi ketentuan peraturan perundang-undngan yang dapat berbeda dengan prinsip akuntansi yang berlaku umum.Laporan keuangan yang disajikan berdasarkan pernyataan ini tidak dimaksudkan untuk memenuhi peraturan perundang-undangan tersebut.

Bank dapat bertindak sebagai pemilik dana maupun pengelola dana. Apabila bank bertindak sebagai pemlik dana, makadana yang disalurkan disebut pembiayaan mudharabah. Apabila bank sebagai pengelola dana, maka dana yang diterima diakui sebagai:

1. Mudharabah muqayyadah maka disajikan dalam laporan perubahan investasi terikat sebagai investasi nasabah; atau

2. Mudharabah mutlaqah maka disajikan dalam nerca sebagai investasi tidak terikat [9].

Pengambilan pembiayaan mudharabah dapat dilakukan bersama dengan distribusi bagi hasil atau pada saat diakhirinya mudharabah. Pada prinsipnya dalam pembiayaan mudharabah tidak ada jaminan, namun pengelola dana tidak melakukan penyimpangan. Pemilik dana dapat meminta jaminan dari pengelola dana atau pihak ketiga. Jaminan ini hanya dapat dicairkan apabila pengelola dana terbukti melakukan pelanggaran terhadap hal-hal yang telah disepakati bersama dalam akad.

\section{Bank Sebagai Shahibul Maal (Pemilik Dana)}

Setiap pembayaran kembali atas pembayaran nudharabah oleh pengelola dana mengurangi saldo pembayaran mudharabah. Apabila sebagian pembiayaan mudharabah hilang sebelum dimulainya usaha 
karena adanya kerusakan atau sebab lainya tanpa adanya kelalaian atu kesalahan pihak pengelola dana, maka rugi tersebut mengurangi saldo pembayaran mudharabah dan diakui sebagai kerugian bank. Apabila pembiayaan diberikan dalam bentuk nonkas maka kegiatan usaha mudharabah dianggap mulai berjalan sejak barang tersebut diterima oleh pengelola dana dalam kondisi siap dipergunakan. Apabila sebagian pembiayaan mudharabah hilang setelah dimulainya usaha tanpa adanya kelalaian atau kesalahan pengelola dana, maka rugi tersebut diperhitungkan pada saat bagi hasil. Apabila pembiayaan diberikan dalam bentuk nonkas dan barang tersebut mengalami penurunan nilai pada saat atau setelah barang dipergunakan secara efektif dalam kegiatan usaha, maka rugi tersebut tidak langsung mengurangi jumlah pembiayaan namun diperhitungkan pada saat pembagian bagi hasil.

\section{Bank Sebagai Mudharib (Pengelola Dana)}

Dana investasi tidak terikat diakui sebagai investasi tidak terikat pada saat terjadinya sebesar jumlah yang diterima.Pada akhir perode akuntansi, investasi tidak terikat diukur sebesar nilai tercatat. Bagi hasil investasi tidak terikat dibagikan kepada bank dan pemilik dana sesuai dengan nisbah yang disepakati. Bagi hasil mudharabah dapat dilakukan dengan menggunakan dua metode, yaitu bagi laba (profit sharing) atau bagi pendapatan (revenue sharing)

\section{Bank Sebagai Agen Investasi}

Apabila bank bertindak sebagai agen dalam menyalurkan dana mudharabah muqayyadah dan bank tidak menanggung resiko (channeling agent), maka pelaporannya tidak dilakukan dalam neraca tetapi dalam laporan perubahan dana investasi terikat. Sedangkan dana yang diterima dan belum disalurkan diakui sebagai titipan. Apabila bank bertindak sebagai agen dalan menyalurkan dana mudharabah atau investasi terikat tetapi bank menanggung resiko atas penyaluran 
dana tersebut (executing agent) maka pelaporanya dilakukan dalam neraca sebesar porsi resiko yang ditanggung oleh bank.

\section{Penyajian dalam Akuntansi Bank Syariah}

Penyajian dalam akuntansi bank syariah telah diatur dengan pedoman (PSAK) dan Pedoman Akuntansi Perbankan Syariah Indonesia (PAPSI).Oleh karena itu, laporan keuangan harus mampu memfasilitasi semua pihak yang terikat dengan bank syariah. Kekurangan perhatian PSAK dan PAPSI dalam masalah syariah juga terdapat dalam hal fungsi laporan keuangan memfasilitasi DPS untuk memeriksa dana nonhalal yang diterima oleh bank. Dana nonhalal berdasarkan PSAK No. 59 dan PAPSI digabung dengan dana qardh. Penggabungan dapat menimbulkan persoalan syariah berupa tercampurnya yang haq dan yang bathil. Ketiadaan pemeriksaan akan menyebabkan kurangnya perhatian untuk mengupayakan pengeliminasian dana nonhalal dimasa yang akan datang. Laporan keuangan bank syariah yang lengkap terdiri dari komponenkomponen berikut :

1. Neraca

2. Laporan laba rugi

3. Laporan arus kas

4. Laporan perubahan ekuitas

5. Laporan perubahan dana investasi terikat

6. Laporan sumber dan penggunaan dana zakat, infak, dan shadaqah

7. Laporan sumber dan penggunaan dana qardhul hasan

8. Catatan atas laporan keuangan.

\section{Pengungkapan dalam Akuntansi Bank Syariah}

Laporan keuangan bank syariah yang diperlihatkan pada bagian sebelumnya mengungkapkan inforasi umum mengenai bank sebagaimana 
diatur dalam ketentuan yang berlaku umum, dengan pengungkapan tambahan yang mencakup, tetapi tidak terbatas pada :

1. Karakteristik kegiatan bank syariah dan jasa utama yang disediakan.

2. Peranan, sifat, dan kewenangan Dewan Pengawas Syariah (DPS) dalam mengawasi kegiatan bank syariah berdasarkan ketentuan hukum dan praktik.

3. Tanggung jawab bank terhadap pengelola zakat.

Laporan keuangan bank syariah mengungkapkan kebijakan akuntansi yang digunakan dalam penyusunan laporan keuangan yang mencakup, tetapi tidak terbatas pada kebijakan akuntansi:

1. Mengenai pemilihan metode akuntansi diantara beberapa alternatif metode akuntansi yang diperbolehkan dalam setiap jenis transaksi.

2. Yang tidak konsisten dengan konsep akuntansi keuangan bank syariah, jika ada.

3. Mengenai pengakuan pendapatan, baban, keuntungan, dan kerugian dalam setiap jenis transaksi.

4. Mengenai pengakuan dan penentuan penyisihan kerugian dan penghapusan aktiva produktif bank syariah.

5. Konsolidasi laporan keuangan, jka ada.

Laporan keuangan bank syariah mengungkapkan pendapatan atau beban yang dilarang oleh bank syariah, jika ada, mengenai :

1. Jumlah dan sifat pendapatan yang diperoleh dari sumber atau cara yang tidak diperkenakan oleh syariah.

2. Jumlah dan sifat beban yang tidak sesuai dengan syariah.

3. Rencana penggunaan pendapatan non halal sesuai dengan arahan Dewan Pengawas Syariah.

Laporan keuangan bank syariah mengungkapkan jumlah saldo dana investasi tidak terikat berdasarkan segmen geografis dan periode jatuh temponya. Selain itu, juga mengungkapkan metode alokasi keuntungan (kerugian) investasi antara pemilik dana investasi tidak terikat dan bank, 
baik bank sebagai pengelola dana maupun bank sebagai agen investasi.Pengungkapan tersebut meliputi :

1. Metode yang digunakan bank untuk menentukan bagian keuntungan atau kerugian dari dana tidak terikat dalam periode yang bersangkutan.

2. Tingkat pengembalian nisbah kedudukan yang disepakati dari masingmasing dana investasi [12]

\section{KESIMPULAN}

Berdasarkan hasil penelitian yang dilakukan pada Bank Mandiri Syariah Cabang Kota Baubau, dapat disimpulkan bahwa ada dua akad yang digunakan dalam bagi hasil yaitu: akad mudharabah dan akad musyarakah sesuai PSAK 105 (paragraf 4) dan PSAK 106 dan pengakuan keuntungan/kerugiannya, Bank Syariah memiliki sistem bagi hasil yang dijalankan, khususnya Bank Mandiri Syariah Cabang Kota Baubau memiliki sistem bagi hasil yang digunakan dalam menjalankan proses bagi hasil sesuai persyaratan dan peraturan berlaku. Dalam penentuan bagi hasil, tentunya kebijakan dan kesepakatan awal sangat mempengaruhi pembagian bagi hasil. Dimana kesepakatan antara pemilik modal dan pengelola modal menentukan pembagian bagi hasil atas pengelolaan dana tersebut. Perhitungan bagi hasil untuk nasabah telah ditentukan melalui rumus yang telah disediakan.

\section{SARAN}

Dari hasil penelitian yang telah dilakukan dan didasarkan pada kesimpulan yang telah disebutkan diatas, maka saran dari penulis yaitu perlunya promosi dan penjelasan lebih rincih mengenai sistem dan tujuan Bank Mandiri Syariah dalam masyarakat Kota Baubau agar pengetahuan tentang tujuan dari bank syariah lebih dipahami dan dimengerti, dan memperhatikan dan memeriksa dana yang dikelola berupa dana halal atau dana nonhalal, sesuai dengan PSAK dan PAPSI dalam masalah fungsi laporan keuangan untuk memeriksa dana nonhalal yang diterima oleh bank. 


\section{DAFTAR PUSTAKA}

[1] Rindawati, 2007. Analisa Perbandingan Kinerja Perbankan Syariah dengan Perbankan Konvensional. UII, Yogyakarta.

[2] Sugiyono.2013.Metode Penelitian Kuantitatif, Kualitatif Dan R\&D. Bandung. Alfabeta.

[3] Priyono, 2008. Metode Penelitian Kuantitatif. Zifatama Publishing. Jawa Timur.

[4] Walidin, W., Saifullah, Tabrani, 2015. Metode Peenelitian Kualitatif dan Grounded Theory. FTK Ar-Rainy Press. Banda Aceh.

[5] Soejono dan Abdurrahman, 2011. Metode Penelitian Suatu Pemikiran dan Penerapan. Rineka Cipta. Jakarta.

[6] Sekaran, Uma. 2011. Metode Penelitian Ilmiah. Jakarta: Salemba Empat.

[7] Sutrisno, Hadi. 2013.Metodologi Penelitian. Yogyakarta: Fakultas Psikologi Universitas Gajah Mada.

[8] Ascarya (2012). Akad dan Produk Bank Syariah, Raja Grafindo Persada, Jakarta.

[9] Rifqi Muhammad. 2008.Akuntansi Keuangan Syariah, Konsep dan implementasi PSAK Syariah.Yogyakarta: P3EI Press.

[10] Ikatan Akuntan Indonesia. Standar Akuntansi Keuangan Syariah. PSAK 105 Akuntansi Mudharabah.

[11] Ikatan Akuntan Indonesia. Standar Akuntansi Keuangan Syariah. PSAK 106 Akuntansi Musyarakah.

[12] Sofian, S, H., Wirosa, Yusuf, M., 2010. Akuntansi Perbankan Syariah. Lembaga Penerbit Fakultas Ekonomi. Universitas Trisakti 